\title{
PENGARUH KETERAMPILAN MENGAJAR GURU TERHADAP HASIL BELAJAR SISWA SMA SE-KOTA MALANG YANG DI KONTROL DENGAN VARIASI SUMBER BELAJAR
}

\author{
Berta Dian Theodora \\ Universitas Indraprasta PGRI Jakarta \\ Berta.dtos@gmail.com
}

\begin{abstract}
This study was aimed to investigate the influence of teacher's teaching skill towards students' learning achievement in SMAN in Malang as controlled by various learning resources. This study used the quantitative approach. The population was the economic teachers in SMAN in Malang. Simple random sampling was used as the method in determining the samples. The data was collected through the observation, questionnaire and documentation. To analyze the data, the t-test and the ANNOVA Two Way with interaction were used.The findings of the study showed that (1) there was a significant difference in the learning achievement between the students who were taught by the teacher with high teaching skill and the students who were taught by the teacher with low teaching skill, (2) there was a significant difference in learning achievement between the students who were taught by using various learning resources and the students who were not, (3) there is no any significant difference in learning achievement between the students who were taught by the high teaching skill teacher with the various learning resources and the students who were taught by the high teaching skill teacher with the various learning resources, (4) there was a significant differences in learning achievement between the students who were taught by the high teaching skill teacher without using various learning resources and the students who were taught by the low teaching skill teacher without using various learning resources, (5) there was no any significant difference of in learning achievement between the students who were taught by the high teaching skill teacher with the various learning resources and the students who were taught by the high teaching skill without using the various learning resources, (6) there was a significant difference of the in learning achievement between the students who were taught by the low teaching skill with the various learning resources and the students who were taught by the low teaching skill teacher without using various learning resources, and (7) the teacher's teaching skill interacts with the various teaching-learning resources and influences significantly on the students' learning achievement..
\end{abstract}

Keywords: Teaching Skill, Students' Learning Achievement, Various Learning Resources.

\begin{abstract}
Abstrak : Penelitian ini bertujuan untuk menguji pengaruh keterampilan mengajar guru terhadap hasil belajar siswa SMA Negeri se-Kota Malang yang di kontrol dengan variasi sumber belajar. Penelitian ini menggunakan pendekatan kuantitatif. Populasi dalam penelitian adalah seluruh guru ekonomi Sekolah Menengah Atas Negeri se-kota Malang. Proses penarikan sampel menggunakan teknik simpel random sampling. Proses pengumpulan data menggunakan kuesioner, observasi dan dokumentasi. Uji Lanjutan untuk analisis data menggunakan analisis varian dua jalur dengan interaksi dan dilakukan uji lanjutan uji beda t-test.Temuan penelitian menunjukkan bahwa (1) terdapat perbedaan yang signifikan antara hasil belajar siswa yang diajarkan oleh guru dengan keterampilan
\end{abstract}


mengajar tinggi dengan hasil belajar siswa yang diajarkan guru berketerampilan mengajar rendah, (2) terdapat perbedaan yang signifikan antara hasil belajar siswa yang diajarkan oleh guru dengan sumber belajar bervariasi dengan hasil belajar siswa yang diajarkan oleh guru yang menggunakan sumber belajar tidak bervariasi, (3) tidak terdapat perbedaan yang signifikan antara hasil belajar siswa yang diajarkan oleh guru dengan keterampilan mengajar tinggi menggunakan sumber belajar bervariasi dibedakan dengan hasil belajar siswa yang diajarkan oleh guru dengan keterampilan mengajar rendah menggunakan sumber belajar bervariasi, (4) terdapat perbedaan yang signifikan antara hasil belajar siswa yang diajarkan oleh guru dengan keterampilan mengajar tinggi menggunakan sumber belajar tidak bervariasi jika dibedakan dengan hasil belajar siswa yang diajarkan guru dengan keterampilan mengajar rendah menggunakan sumber belajar tidak bervariasi, (5) tidak terdapat perbedaan yang signifikan antara hasil belajar siswa yang diajarkan oleh guru yang menggunakan sumber belajar bervariasi dengan keterampilan mengajar tinggi jika dibedakan dengan hasil belajar siswa dari guru yang menggunakan sumber belajar tidak bervariasi berketerampilan mengajar tinggi, (6) terdapat perbedaan yang signifikan antara hasil belajar siswa yang diajarkan oleh guru yang menggunakan sumber belajar bervariasi dengan keterampilan mengajar rendah jika dibedakan dengan hasil belajar siswa dari guru yang menggunakan sumber belajar tidak bervariasi berketerampilan mengajar rendah, dan (7) keterampilan megajar guru berinteraksi dengan variasi sumber belajar dan secara bersama-sama berpengaruh signifikan terhadap hasil belajar siswa.

Pendidikan merupakan faktor utama dalam pembentukan pribadi manusia menurut ukuran normatif. Penyelenggaraan pendidikan pada hakekatnya memiliki tujuan utama untuk menghasilkan dan menguasai ilmu pengetahuan, teknologi dan seni serta dapat menghasilkan lulusan dan anak didik yang bisa mengikuti perkembangan zaman.

Penelitian menunjukkan lebih dari tiga puluh persen keberhasilan pendidikan yang ditunjukkan oleh indikator prestasi belajar siswa ditentukan oleh guru (Supriadi, 1998). Oleh karenanya kemampuan guru dalam pengelolaan pembelajaran perlu mendapat perhatian yang serius. Winataputra (2007) mengemukakan bahwa sumber pembelajaran IPS dapat menggunakan buku sumber (buku teks, majalah atau koran dan media massa lainnya), media dan alat pengajaran, situasi dan kondisi kelas serta lingkungan. Kurang optimalnya pembelajaran di sekolah diungkapkan oleh Karwono (1993) melalui hasil penelitiannya, bahwa sumber belajar yang beraneka ragam di sekitar sekolah dan kehidupan murid ternyata belum dimanfaatkan secara maksimal untuk mengembangkan pembelajaran bidang studi. Oleh karenanya pengajar dituntut memiliki kemampuan menggunakan sumber belajar.

\section{Keterampilan Mengajar}

Keterampilan mengajar pada dasarnya adalah kemampuan-kemampuan khusus berkenaan dengan aspek-aspek pelaksanaan kegiatan pembelajaran yang harus dimiliki dan diterapkan oleh setiap orang yang memiliki profesi sebagai guru, tutor, pelatih maupun fasilitator dalam melaksanakan pembelajaran. Pintrich \& Schunk (2002) menggambarkan enam aspek keterampilan guru mengajar. Keenam aspek tersebut yaitu: (1) Mengulas pembelajaran sebelumnya, (2) Memberikan materi baru, (3) Memberikan latihan, (4) Memberikan umpan balik (feedback), (5) Memberikan latihan mandiri, dan (6) Mengulas kembali materi yang telah diajarkan. Adapun beberapa kemampuan khusus berkaitan dengan keterampilan pelaksanaan pembelajaran 
tersebut, dikemukakan oleh Allen dan Ryan dalam lembar monitoring dan evaluasi pelaksanaan pembelajaran yang dikeluarkan oleh Departemen Pendidikan Nasional (2008) yaitu (1) Membuka Pembelajaran (Set Induction), (2) Variasi Stimulus (Stimulus Variation), (3) Keterampilan Bertanya (Question), (4) Isyarat (Silence and Non Verbal Clue), (5) Ilustrasi/ Penggunaan Contoh (Illustration and Use of Example), (6) Kemampuan Berkomunikasi (Communication), (7) Penguatan dan Balikan (Reinforcement and Feed Back), (8) Siasat Menutup Pembelajaran (Closure).

\section{Variasi Sumber Belajar}

AECT (Association for Education Communication Technology) mendefinisikan sumber belajar adalah orang, alat-alat, teknologi dan materi yang sengaja di desain

Tabel 1 Klasifiaksi Sumber Belajar untuk menolong siswa dalam belajar. Sumber daya dapat mencakup teknologi tinggi sistem ICT, sumber daya masyarakat seperti perpustakaan, kebun binatang, museum, dan orang-orang dengan pengetahuan khusus atau keahlian.

Membuat klasifikasi sumber belajar tidak mudah dan sangat tergantung dari sudut pandangnya, sebagaimana disebutkan Sudjana dan Rifai (2005) yang mengklasifikasikan sumber belajar menjadi dua bagian yaitu (1) sumber belajar yang dirancang atau sengaja dibuat (learning resources by design ). (2) Sumber belajar yang dimanfaatkan dalam belajar berupa segala macam sumber belajar yang ada di sekeliling kita, tidak dirancang untuk kepentingan tujuan suatu kegiatan pembelajaran. Sumber belajar ini disebut learning resources by utilization.

\begin{tabular}{|c|c|c|c|c|}
\hline \multirow[b]{2}{*}{ No } & \multirow{2}{*}{$\begin{array}{l}\text { Jenis } \\
\text { Sumber } \\
\text { Belajar }\end{array}$} & \multirow[b]{2}{*}{ Pengertian } & \multicolumn{2}{|c|}{ Contoh } \\
\hline & & & By design & By utilization \\
\hline 1 & Pesan & $\begin{array}{l}\text { Informasi yang harus disalurkan oleh } \\
\text { komponen lain berbentuk ide, fakta, } \\
\text { pengertian dan data }\end{array}$ & Bahan pelajaran & $\begin{array}{l}\text { Cerita rakyat, } \\
\text { dongeng }\end{array}$ \\
\hline 2 & $\begin{array}{l}\text { Manusia } \\
\text { (people) }\end{array}$ & $\begin{array}{l}\text { Orang yang menyimpan informasi } \\
\text { atau menyalurkan informasi }\end{array}$ & Guru, siswa, pembicara & $\begin{array}{l}\text { Narasumber, } \\
\text { masyarakat, } \\
\text { responden }\end{array}$ \\
\hline 3 & $\begin{array}{l}\text { Bahan } \\
\text { (Material) }\end{array}$ & $\begin{array}{l}\text { Sesuatu yang disebut program } \\
\text { (software) yang mengandung pesan } \\
\text { untuk disajikan, melalui penggunaan } \\
\text { alat ataupun oleh dirinya }\end{array}$ & $\begin{array}{l}\text { Transparansi, slide, film, } \\
\text { tape, buku, majalah }\end{array}$ & $\begin{array}{l}\text { Relief, candi arca, } \\
\text { peralatan teknik }\end{array}$ \\
\hline 4 & $\begin{array}{l}\text { Alat } \\
\text { (device) }\end{array}$ & $\begin{array}{l}\text { Sesuatu yang disebut (hardware) } \\
\text { atau perangkat keras yang digunakan } \\
\text { untuk menyampaikan pesan yang } \\
\text { tersimpan didalam materi }\end{array}$ & $\begin{array}{l}\text { Proyeksi slide, filmstrip, } \\
\text { OHP, TV }\end{array}$ & $\begin{array}{l}\text { Generator, alat- } \\
\text { alat mobil, mesin. }\end{array}$ \\
\hline 5 & $\begin{array}{l}\text { Teknik } \\
\text { (technique) }\end{array}$ & $\begin{array}{l}\text { Prosedur yang di siapkan dalam } \\
\text { mempergunakan bahan, peralatan, } \\
\text { orang dan lingkungan untuk } \\
\text { menyampaikan pesan }\end{array}$ & $\begin{array}{l}\text { Ceramah, pembelajaran } \\
\text { berprogram, discovery, } \\
\text { kuliah, simulasi }\end{array}$ & $\begin{array}{l}\text { Percakapan biasa } \\
\text { atau spontan }\end{array}$ \\
\hline 6 & $\begin{array}{l}\text { Lingkungan } \\
\text { (setting) }\end{array}$ & $\begin{array}{l}\text { Situasi sekitar dimana pesan } \\
\text { diterima }\end{array}$ & $\begin{array}{l}\text { Lingkungan fisik, gedung } \\
\text { sekolah, perpustakaan, } \\
\text { laboratorium, meseum } \\
\text { dan lain-lain }\end{array}$ & $\begin{array}{l}\text { Taman, kebun, } \\
\text { pasar }\end{array}$ \\
\hline
\end{tabular}


Sumber belajar yang ketersediaannya dirasa kurang, dapat menghambat pembelajaran untuk siswa, karena sumber belajar merupakan salah satu bagian dari strategi pembelajaran yang dilakukan oleh guru. Oleh karenanya ketersediaan sumber belajar dan bervariasinya sumber belajar sangat penting bagi guru dan siswa untuk mendukung proses pembelajaran

\section{Hasil Belajar}

Hasil belajar yang dicapai siswa dipengaruhi oleh dua faktor utama yakni faktor dari dalam diri siswa dan faktor yang datang dari luar siswa.

Dalam lingkungan belajar di sekolah, hal yang paling dominan mempengaruhi hasil belajar ialah kualitas pembelajaran. Hal ini tidak berbeda dengan penjelasan Klausmer dan Goodwin (1971) mengenai faktor-faktor yang mempengaruhi hasil belajar di sekolah adalah (1) karakteristik siswa, (2) faktor pengajar atau dosen, (3) faktor bahan atau materi yang akan dipelajari, (4) media pembelajaran, (5) karakteristik fisik sekolah dan (6) faktor lingkungan dan situasional. Menurut Uno (2009) "pada dasarnya perubahan perilaku yang dapat ditunjukan oleh peserta didik harus dipengaruhi oleh latar belakang pendidikan dan pengalaman yang dimiliki seorang guru".

\section{Hipotesis}

Berdasarkan teori-teori, pendapatpendapat serta hasil penelitian yang dikemukakan maka hipotesis yang diajukan adalah:

1. Adakah perbedaan yang signifikan antara guru dengan keterampilan mengajar tinggi dengan rendah terhadap hasil belajar.

2. Adakah perbedaan yang signifikan antara guru yang menggunakan sumber belajar bervariasi dengan guru yang menggunakan sumber belajar tidak bervariasi terhadap hasil belajar.

3. Adakah perbedaan yang signifikan antara guru dengan keterampilan mengajar tinggi menggunakan sumber belajar bervariasi dengan guru berketerampilan mengajar rendah menggunakan sumber belajar bervariasi terhadap hasil belajar

4. Adakah perbedaan yang signifikan antara guru dengan keterampilan mengajar tinggi menggunakan sumber belajar tidak bervariasi dengan guru berketerampilan mengajar rendah menggunakan sumber belajar tidak bervariasi terhadap hasil belajar

5. Adakah perbedaan yang signifikan antara guru yang menggunakan sumber belajar bervariasi dengan keterampilan mengajar tinggi dengan guru yang menggunakan sumber belajar tidak bervariasi berketerampilan mengajar tinggi terhadap hasil belajar

6. Adakah perbedaan yang signifikan antara guru yang menggunakan sumber belajar bervariasi dengan keterampilan mengajar rendah dengan guru yang menggunakan sumber belajar tidak bervariasi berketerampilan mengajar rendah terhadap hasil belajar

7. Adakah pengaruh atas interaksi antara keterampilan mengajar guru dengan variasi sumber belajar terhadap hasil belajar siswa.

\section{METODE}

Penelitian ini bertujuan untuk mendeskripsikan dan menganalisis hubungan antara tiga variabel. Rancangan penelitian yang digunakan oleh peneliti dalam penelitian ini merupakan penelitian eksplanatori dengan pendekatan desain faktorial. Subjek penelitian ini adalah guru 
ekonomi SMAN se-Kota Malang. Penentuan sampel dilakukan dengan teknik simple random sampling.

Skala pengukuran angket dalam penelitian ini menggunakan skala guttman. Sebelum data di analisis menggunakan analisis deksriptif, analisis Anova dua jalur dengan interaksi dan t-test, dilakukan uji validitas dan reliabilitas angket, juga dilakukan uji prasyarat analisis. Dalam penelitian ini variabel terikat dan bebas berupa keterampilan mengajar guru $\left(\mathrm{X}_{1}\right)$, variasi sumber belajar $\left(\mathrm{X}_{2}\right)$ dan hasil belajar siswa $(\mathrm{Y})$.

\section{HASIL DAN PEMBAHASAN}

Hasil penelitian dibedakan menjadi dua macam yang terdiri dari:
1. Hasil penelitian yang diperoleh dari pengolahan data dengan menggunakan statistik deskriptif, hal ini berguna untuk mendeskripsikan distribusi skor variabel terikat dan bebas.

2. Hasil penelitian yang diperoleh dari pengolahan data dengan analisis Anova dua jalur dengan interaksi dan t-test, yaitu untuk mengetahui apakah terdapat perbedaan antara variabel terikat dalam mempengaruhi variabel bebas.

a. Hasil analisis deskriptif, menunjukan bahwa keterampilan mengajar guru, variasi sumber belajar cenderung berada pada kategori rendah sedangkan hasil belajar siswa berada pada kategori tinggi. Lebih jelasnya dapat dilihat pada tabel 2 .

Tabel 2. Distribusi Frekuensi

\begin{tabular}{|c|c|c|c|c|}
\hline No & Interval & Kategori & Frekuensi & Persentase \\
\hline \multicolumn{5}{|c|}{ Keterampilan Mengajar Guru } \\
\hline 1. & $>37,03$ & Tinggi & 15 & 46,9 \\
\hline 2. & $<37,03$ & Rendah & 17 & 53,1 \\
\hline \multicolumn{5}{|c|}{ Variasi Sumber Belajar } \\
\hline 1. & $>10,22$ & Tinggi & 13 & 40,6 \\
\hline 2. & $<10,22$ & Rendah & 19 & 59,4 \\
\hline \multicolumn{5}{|c|}{ Hasil Belajar Siswa } \\
\hline 1. & $>76,26$ & Tinggi & 21 & 65,6 \\
\hline 2. & $<76,26$ & Rendah & 11 & 34,4 \\
\hline
\end{tabular}

Sumber: Data diolah Peneliti, 2013

Berdasarkan tabel 2 dapat dilihat bahwa guru ekonomi belum memiliki keterampilan mengajar yang memadai terlihat bahwa terdapat $<50 \%$ guru yang berada pada kategori tinggi, hal ini terlihat pula dalam variasi penggunaan sumber belajar dimana terdapat $<50 \%$ guru yang berada pada kategori tinggi.

Dari hasil belajar siswa pada nilai ujian tengah semester pada semester II tahun ajaran 2012/2013 diketahui bahwa hasil belajar siswa dalam kategori tinggi sejumlah $65,6 \%$. b. Analisis Data Statistik, menghasilkan output data seperti dilihat pada tabel 3. Berdasarkan tabel 3, maka hasil analisis dapat disimpulkan bahwa: a) terdapat perbedaan antara keterampilan mengajar tinggi dan rendah $(\operatorname{sig}<0,05)$ terhadap hasil belajar. b) terdapat perbedaan antara guru yang menggunakan sumber belajar bervariasi dengan tidak bervariasi $(\operatorname{sig}<0,05)$ terhadap hasil belajar, dan $\mathrm{c})$ terdapat interaksi antara keterampilan mengajar guru dan variasi sumber belajar terhadap hasil belajar $(\operatorname{sig}<0,05)$. 
Tabel 3. Uji Anova dengan interaksi

\begin{tabular}{|l|c|l|l|l|c|}
\hline \multicolumn{1}{|c|}{ Sk } & df & $\begin{array}{l}\text { Sum of } \\
\text { Square }\end{array}$ & $\begin{array}{l}\text { Mean } \\
\text { Square }\end{array}$ & F $_{\text {hitung }}$ & Sig \\
\hline KMG & 6 & 772,479 & 128,747 & 15,136 & 0,000 \\
\hline VSB & 5 & 428,935 & 85,787 & 10,086 & 0,001 \\
\hline KMG*VSB & 8 & 257,915 & 32,239 & 3,790 & 0,019 \\
\hline
\end{tabular}

Sumber: Data diolah Peneliti, 2013

Dilakukan uji lanjutan menggunakan t-test terjadi antar kategori yang ada. untuk mengetahui adakah perbedaan yang

\section{Tabel 4 Rangkuman Hasil t-test}

\begin{tabular}{|c|c|c|c|}
\hline No & $\begin{array}{l}\text { Hasil } \\
\text { Analisis } \\
\text { (Sig) }\end{array}$ & $\begin{array}{l}\text { Pengujian } \\
\text { Hipotesis }\end{array}$ & Kesimpulan \\
\hline 1 & 0,004 & $\begin{array}{l}\text { Sig }<0,05 \\
\mathrm{H}_{0} \text { ditolak } \\
\text { berbeda }\end{array}$ & $\begin{array}{l}\text { Hasil belajar siswa yang diajar oleh guru berketerampilan } \\
\text { mengajar tinggi berbeda dengan hasil belajar siswa yang diajar } \\
\text { oleh guru dengan berketerampilan mengajar rendah }\end{array}$ \\
\hline 2 & 0,005 & $\begin{array}{l}\text { Sig }<0,05 \\
\mathrm{H}_{0} \text { ditolak; } \\
\text { berbeda }\end{array}$ & $\begin{array}{l}\text { Hasil belajar siswa yang diajar oleh guru yang menggunakan } \\
\text { sumber belajar bervariasi berbeda dengan hasil belajar siswa } \\
\text { yang diajar oleh guru yang menggunakan sumber belajar tidak } \\
\text { bervariasi }\end{array}$ \\
\hline 3 & 0,583 & $\begin{array}{l}\text { Sig }>0,05 \\
\mathrm{H}_{0} \text { diterima; } \\
\quad \text { tidak } \\
\text { berbeda }\end{array}$ & $\begin{array}{l}\text { Hasil belajar siswa yang diajar oleh guru dengan keterampilan } \\
\text { mengajar tinggi menggunakan sumber belajar bervariasi tidak } \\
\text { berbeda dengan hasil belajar siswa yang diajar oleh guru } \\
\text { berketerampilan mengajar rendah menggunakan sumber belajar } \\
\text { bervariasi }\end{array}$ \\
\hline 4 & 0,004 & $\begin{array}{l}\text { Sig }<0,05 \\
\mathrm{H}_{0} \text { ditolak; } \\
\text { berbeda }\end{array}$ & $\begin{array}{l}\text { Hasil Belajar siswa yang diajar oleh guru dengan keterampilan } \\
\text { mengajar tinggi menggunakan sumber belajar tidak bervariasi } \\
\text { berbeda dengan hasil belajar siswa yang diajar oleh guru } \\
\text { berketerampilan mengajar rendah menggunakan sumber belajar } \\
\text { tidak bervariasi }\end{array}$ \\
\hline 5 & 0,574 & $\begin{array}{l}\text { Sig }>0,05 \\
\mathrm{H}_{0} \text { diterima; } \\
\quad \text { tidak } \\
\text { berbeda }\end{array}$ & $\begin{array}{l}\text { Hasil belajar siswa yang diajar oleh guru menggunakan sumber } \\
\text { belajar bervariasi dengan keterampilan mengajar tinggi tidak } \\
\text { berbeda dengan hasil belajar siswa yang diajar oleh guru yang } \\
\text { menggunakan sumber belajar tidak bervariasi berketerampilan } \\
\text { mengajar tinggi }\end{array}$ \\
\hline 6 & 0,007 & $\begin{array}{l}\text { Sig }<0,05 \\
\mathrm{H}_{0} \text { ditolak; } \\
\text { berbeda }\end{array}$ & $\begin{array}{l}\text { Hasil belajar siswa yang diajarkan oleh guru yang menggunakan } \\
\text { sumber belajar bervariasi dan keterampilan mengajar rendah } \\
\text { berbeda dengan hasil belajar siswa yang diajarkan guru yang } \\
\text { menggunakan sumber belajar tidak bervariasi berketerampilan } \\
\text { mengajar rendah }\end{array}$ \\
\hline 7 & 0,019 & $\begin{array}{l}\text { Sig }<0,05 \\
\mathrm{H}_{0} \text { ditolak; } \\
\text { terdapat } \\
\text { interaksi }\end{array}$ & $\begin{array}{l}\text { Terdapat interaksi antara keterampilan mengajar guru dengan } \\
\text { variasi sumber belajar terhadap hasil belajar }\end{array}$ \\
\hline
\end{tabular}

Sumber: Data diolah Peneliti, 2013 


\section{Hipotesis 1:}

Berdasarkan hasil analisis data yang sudah diuraikan pada tabel 4, dapat dibukti bahwa terdapat perbedaan yang signifikan antara guru dengan keterampilan mengajar tinggi dengan guru yang memiliki keterampilan mengajar rendah terhadap hasil belajar siswa. Hal ini menunjukkan bahwa tingkat keterampilan mengajar guru akan berdampak pada perbedaan pencapaian hasil belajar yang diperoleh disekolah. Hasil ini membuktikan relevansi teori yang dikemukakan oleh Uno (2009) yang menyatakan bahwa pada dasarnya perubahan perilaku yang dapat ditunjukan oleh peserta didik harus dipengaruhi oleh latar belakang pendidikan dan pengalaman yang dimiliki seorang guru. Oleh karena itu semakin tinggi tingkat keterampilan mengajar guru akan berpengaruh juga pada hasil belajar yang diperoleh siswa.

\section{Hipotesis 2:}

Berdasarkan hasil analisis data yang sudah diuraikan pada table 4, terdapat bukti bahwa terdapat perbedaan yang signifikan antara penggunaan sumber belajar yang bervariasi dengan yang tidak bervariasi dalam proses pembelajaran yang nantinya berpengaruh terhadap hasil belajar siswa. Hal ini menunjukkan bahwa variasi sumber belajar berdampak terhadap pencapaian hasil belajar siswa di sekolah.

Penggunaan sumber belajar yang bervariasi akan berpengaruh terhadap hasil belajar sejalan dengan penelitian yang dilakukan oleh Purwoko (2011), disimpulkan bahwa variasi sumber belajar dapat meningkatkan hasil belajar siswa SMK.

\section{Hipotesis 3:}

Berdasarkan hasil analisis data pada tabel 4, terdapat bukti bahwa tidak terdapat perbedaan yang signifikan antara guru dengan keterampilan mengajar tinggi menggunakan sumber belajar bervariasi dengan guru beketerampilan mengajar rendah menggunakan sumber belajar bervariasi .

Perbedaan keterampilan mengajar guru yang sewajarnya menghasilkan perbedaan pada hasil belajar siswa (hipotesis pertama) ternyata tidak terjadi jika kondisi ini dikontrol dengan adanya variabel lain yaitu penggunaan sumber belajar. Hal ini dapat terjadi karena kekurangan pada guru yang memiliki keterampilan mengajar rendah dapat diperbaiki dengan penggunaan sumber belajar yang bervariasi. Hal ini seperti yang diungkapkan oleh Purwoko (2011) dimana variasi sumber belajar dapat meningkatkan hasil belajar siswa.

\section{Hipotesis 4:}

Berdasarkan hasil analisis data pada tabel 4, terdapat bukti bahwa terdapat perbedaan yang signifikan antara guru dengan keterampilan mengajar tinggi menggunakan sumber belajar yang tidak bervariasi dengan guru berketerampilan mengajar rendah menggunakan sumber belajar tidak bervariasi dalam proses pembelajaran yang nantinya berpengaruh terhadap hasil belajar siswa.

\section{Hipotesis 5:}

Berdasarkan hasil analisis data pada tabel 4, menunjukkan bahwa tidak ada beda hasil belajar siswa pada guru yang menggunakan sumber belajar bervariasi dengan hasil belajar siswa pada guru yang menggunakan sumber belajar tidak bervariasi. Tidak bedanya hasil belajar siswa pada kelompok ini dikarenakan dengan keterampilan mengajar yang dimiliki guru tergolong tinggi, maka guru dapat meningkatkan proses pembelajaran di kelas dengan mengembangkan materi yang tersedia, memberikan pertanyaan yang bervariasi sehingga memacu siswa untuk berfikir kritis dan meningkatkan pengelolaan kelas selama proses pembelajaran berlangsung selain dari penggunaan sumber belajar yang bervariasi. 


\section{Hipotesis 6:}

Berdasarkan hasil analisis data pada tabel 4, menunjukkan bahwa ada beda hasil belajar siswa pada guru yang menggunakan sumber belajar bervariasi dengan hasil belajar siswa pada guru yang menggunakan sumber belajar tidak bervariasi saat disertakan kondisi keterampilan mengajar guru yaitu ketika keterampilan mengajar yang dimiliki guru adalah rendah. Berbedanya hasil belajar siswa pada kelompok ini dikarenakan dengan keterampilan mengajar guru tergolong rendah, maka perbedaan penggunaan sumber belajar akan menjadi salah satu faktor yang akan meningkatkan proses pembelajaran di kelas karena ketika siswa memperoleh beragam sumber belajar maka ia akan lebih mudah dan cepat memahami konsep ekonomi yang ada, seperti hasil pengujian pada hipotesis dua yang menyatakan bahwa perbedaan kondisi variasi sumber belajar akan membedakan hasil belajar siswa.

\section{Hipotesis 7:}

Hasil penelitian menyatakan bahwa keterampilan mengajar guru yang tinggi bila diimbangi dengan penggunaan sumber belajar yang bervariasi akan menghasilkan nilai hasil belajar yang tinggi. Keterampilan mengajar yang dimiliki guru berbeda satu dengan yang lainnya, namun saat keterampilan mengajar yang dimiliki guru adalah tinggi dan yang membedakan dalam proses pembelajaran adalah penggunaan sumber belajar maka untuk mendapatkan hasil belajar yang lebih baik maka guru dengan keterampilan mengajar tinggi sebaiknya menggunakan sumber belajar yang bervariasi. Hal ini terjadi karena ketika siswa memperoleh beragam sumber belajar maka ia akan lebih mudah dan cepat memahami konsep ekonomi yang ada.

Keterampilan mengajar guru merupakan puncak keahlian guru yang profesional sebab merupakan penerapan semua kemampuan yang telah dimiliki dalam hal bahan pengajaran, komunikasi dengan siswa, metode-metode mengajar sehingga dapat menjadikan proses belajar mengajar lebih efektif (Sudjana, 2004) yang pada akhirnya akan meningkatkan hasil belajar siswa.

\section{SIMPULAN DAN SARAN}

Berdasarkan data penelitian serta analisis statistik yang telah diuraikan dapat disimpulkan bahwa penelitian ini membuktikan bahwa apa yang diindikasikan bahwa keterampilan mengajar guru $\left(\mathrm{X}_{1}\right)$ dan variasi sumber belajar $\left(\mathrm{X}_{2}\right)$ diduga berpengaruh terhadap hasil belajar siswa (Y) berlaku sepenuhnya pada kondisi di lingkungan Sekolah Menengah Atas Negeri se-Kota Malang

Berdasarkan hasil penelitian dan pembahasan, maka dapat disarankan beberapa hal sebagai berikut:

1. Kepada guru ekonomi di SMA Negeri se-kota Malang untuk terus meningkatkan keterampilan mengajar khususnya mengenai pengamatan yang dilakukan dan dalam pembelajaran yang dilakukan guru menggunakan sumber belajar yang bervariasi

2. Kepada Kepala Sekolah Menengah Atas se-Kota Malang untuk memfasilitasi guru dalam meningkatkan keterampilan mengajar dan untuk menyediakan sumber belajar yang bervariasi di sekolah agar bisa dimanfaatkan oleh guru dalam pembelajaran.

3. Kepada peneliti selanjutnya

a) Peneliti selanjutnya perlu untuk mempertimbangkan variabel lain yang berbeda dengan penelitian ini agar mendapatkan data yang lebih mendalam dan disarankan menggunakan metode yang berbeda.

b) Peneliti selanjutnya diharapkan dapat melakukan penelitian lanjutan mengenai efektifitas penggunaan sumber belajar yang dipakai oleh 
guru ekonomi dalam pembelajaran.

\section{DAFTAR RUJUKAN}

AECT. 2004. The Definition of Education Technology. Washington Association forEducation Communications and technology. (online) http://www.aect.org/newsite/

Dirjen Peningkatan Mutu Pendidik dan Tenaga Kependidikan.2008. Monitoring dan Evaluasi Pelaksanaan Pembelajaran. Jakarta: Departemen Pendidikan Nasional

Karwono. 1993. Pemanfaatan Sumber Belajar Bidang Studi IPS Kelas V Oleh Guru-Guru Sekolah Dasar Di Kecamatan Blimbing Kotamadya Malang, Jawa Timur. Tesis. Tidak diterbitkan Pascasarjana Universitas Negeri Malang

Klausmeir, H. J dan Goodwin, W. (1971). Learning and Human Abilities Educational Psychology. New York:Harper and Row Publisher Pintrich, Paul R \& Dale H. Schunk (2002). Motivation in Education (Theory,
Research, and Application). New Jersey: Prentice-Hall, Inc.

Purwoko, B. 2011. Pengaruh Variasi Sumber Belajar Terhadap Penguasaan Atas Hasil Belajar Kompetensi Menerapkan DasarDasar Elektronika Program Elektronika di SMK Kabupaten Malang. Tesis. Tidak diterbitkan. Pascasarjana Universitas Negeri Malang.

Sudjana, N dan Rivai, A. 2005. Media Pengajaran (Penggunaan dan Pembuatannya). Bandung: Sinar Baru Sudjana, N. 2004. Dasar-dasar Proses Belajar Mengajar. Jakarta:Sinar Baru Algesindo

Supriadi, D.1998. Mengangkat Citra dan Martabat Guru. Yogyakarta: Adicita Karya Nusa

Uno, H.B. 2009. Profesi Kependidikan. Jakarta:PT.Bumi Aksara

Winataputra, U S. 2007. Materi dan Pembelajaran IPS SD. Jakarta : Pusat Penerbitan Universitas Terbuka 